\title{
The pre-history of sustainability reporting: a constructivist reading
}

\section{2}

Received 8 March 2017 Revised 14 October 2019 5 January 2021

31 March 2021 Accepted 7 April 2021
Carlos Larrinaga

Facultad de Ciencias Economicas y Empresariales, Universidad de Burgos, Burgos, Spain, and

Jan Bebbington

Pentland Centre for Sustainability in Business, Lancaster University, Lancaster, UK

\begin{abstract}
Purpose - The aim of this paper is to provide an account of the period prior to the creation of the Global Reporting Initiative (GRI): a body that was critical to the institutionalization of sustainability reporting (SR). By examining this "pre-history," we bring to light the actors, activities and ways of thinking that made SR more likely to be institutionalized once the GRI entrepreneurship came to the fore.

Design/methodology/approach - The paper revisits a time period (the 1990s) that has yet to be formally written about in any depth and traces the early development of what became SR. This material is examined using a constructivist understanding of regulation.

Findings - The authors contend that a convergence of actors and structural conditions were pivotal to the development of SR. Specifically, this paper demonstrates that a combination of actors (such as epistemic communities, carriers, regulators and reporters) as well as the presence of certain conditions (such as the societal context, analogies with financial reporting, environmental reporting and reporting design issues) contributed to the development of SR which was consolidated (as well as extended) in 1999 with the advent of the GRI.

Research limitations/implications - This paper theorizes (through a historical analysis) how SR is sustained by a network of institutional actors and conditions which can assist reflection on future SR development.

Originality/value - This paper brings together empirical material from a time that (sadly) is passing from living memory. The paper also extends the use of a conceptual frame that is starting to influence scholarship in accounting that seeks to understand how norms develop.
\end{abstract}

Keywords Sustainability reporting, Environmental reporting, Normativity

Paper type Research paper

\section{Introduction}

SR [1] is an activity undertaken by the majority of large companies across the globe (Ehnert et al., 2016; Junior et al., 2014; KPMG, 2011, 2013, 2015, 2017, 2020): nearly 100\% of the largest 250 global corporations create some form of report of their social/environmental/ sustainability impacts. This level of practice has led Cho et al. (2015) to suggest that SR has become institutionalized. That is, producing a SR has become a standard business practice, at least for large companies, and the form of accounting has become more similar

(C) Carlos Larrinaga and Jan Bebbington. Published by Emerald Publishing Limited. This article is published under the Creative Commons Attribution (CC BY 4.0) licence. Anyone may reproduce, distribute, translate and create derivative works of this article (for both commercial and non-commercial purposes), subject to full attribution to the original publication and authors. The full terms of this licence may be seen at http://creativecommons.org/licences/by/4.0/legalcode

The authors are grateful to three anonymous referees who pushed us to develop our thinking around this paper. The authors are also grateful for the financial assistance provided by Ministerio de Economía y Competitividad, FEDER and Consejería de Educación, Junta de Castilla y León (Grants ECO201233121, ECO2015-65782-P and BU058P17). Previous drafts of this paper were presented at the 2014 BAFA Conference, at the 2015 EAA Conference, at a CARR/CSEAR workshop in January 2015 in the London School of Economics and in a research seminar at the University of Sydney in 2016. 
over time. This is consistent with a perception that, although SR has often been voluntary for companies, it "has become the de facto law for business (...) [in such a way that] companies not yet reporting on their corporate responsibility activities are under significant pressure to start” (KPMG, 2011, p. 2; emphasis in the original).

An important institutional actor in promoting SR is the GRI who, with their launch of reporting guidelines in 1999, were central to the process of institutionalization. Their "institutional entrepreneurship" and their importance for providing legitimacy to reporting activities is widely recognized (see, e.g., Brown et al., 2009; Etzion and Ferraro, 2010; Levy et al.,2010). This paper does not revisit these insights but provides evidence about how, prior to 1999, a number of actors and processes created the conditions that meant that SR could become institutionalized. This is a time period that is (sadly) starting to pass from living memory: hence there is value to revisiting evidence from and developing insights about this time. The focus of this paper is on United Kingdom (and to some extent European) developments during this time as this was where many of the practices and principles that subsequently underpinned SR were initially developed. In examining this time period, we apply the framework introduced to accounting by Bebbington et al. (2012) to explain how norms of behavior (such as reporting) develop to a state where they are seen as being de facto law (to follow the language used by KPMG).

The aim of this paper is to provide a historical account of how reporting norms emerged from practice, based on the conditions of possibility for the emergence of these norms as well as on the authority of different actors to prescribe, translate and edit those norms. This focus reflects a constructivist understanding of regulation. The paper, therefore, complements existing institutional explanations of SR to provide insight into the role that a variety of actors and institutional conditions played in the emergence of SR. We hypothesize that such reconstruction could help to deepen understand the current configuration of SR as well as its likely future evolution. To address this contention, this paper traces the historical participation of a broad array of actors that transformed corporate and sustainability reporting, together with institutional conditions that provided the required support for this transformation.

The rest of the paper is structured as follows. The second section elaborates further on the notion of SR institutionalization, i.e. on the proposition that SR has become a de facto law for companies. In particular, this section reviews institutional theory and the available information about SR activity, providing the ground for exploring the role structural conditions played in the institutionalization of SR. Accordingly, the third section explores how epistemic communities generated ideas, entrepreneurs innovated, carriers diffused practices and reporters enabled the inscriptions of particular SR norms. The fourth section explores, in turn, how structural conditions, such as analogies with financial reporting, the existence of precedents such as environmental reporting or the appropriate design of norms created the conditions of possibility for different forms of SR to become institutionalized. The final section presents some concluding comments.

\section{An institutional explanation of SR}

In order to provide an institutional explanation of SR we split this section into: first, a consideration as to if SR conforms to the notion of an institution and, second, a discussion of the dynamics of SR institutionalization.

\subsection{The SR institution}

The existence of a SR institution can be explored, first, through the notion of isomorphism/ convergence, defined as the process by which structures and practices are progressively

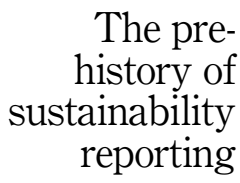

163 
AAAJ

34,9

164

homogenized as a response to converging expectations (DiMaggio and Powell, 1983). There is a declining variance in the activity of producing reports: nearly $100 \%$ of the largest 250 multinational corporations (MNCs thereafter) and all of the 100 largest listed companies in some countries are reporting. An analysis of the GRI databases [2] provides evidence that the number of reports steeply increased between 1999 and 2010, at annual growth rates well above $30 \%$, although after 2014 the annual growth rate has dropped below 10\% (reflecting earlier penetration of reporting practices). Moreover, together with the production of homogenous practices (i.e., the reports), isomorphism is discernible in how SR practices have institutional meaning and conform to a set of converging expectations about appropriate behavior. Institutional meaning is evidenced here by the existence of a shared language (e.g. notions such as stakeholder engagement, materiality or triple bottom line reporting) and by the development of specific metrics. Likewise, certain "rules of the game" (Djelic and SahlinAndersson, 2006) have created expectations and are used to judge reporting companies. For example, a positive value is generally attributed to the provision of some kind of assurance about the information included in SRs (Junior et al., 2014), as well as to the disclosure of stakeholder engagement activity (Rinaldi et al., 2014). In sum, we can safely affirm that some sort of SR institution exists because SR practices and expectations have converged around a set of norms.

The second element of institutions is stability of practices (beyond their existence). In contrast with the inherent contingency of new practices hypothesized by rationalistic approaches (Birkinshaw et al., 2008; Lieberman and Asaba, 2006), institutional theory conceives of institutions as "chronically reproducing complexes of routines, rules, roles, and meanings" (Jepperson and Meyer, 2011, p. 64): institutions are therefore resistant to change (Scott, 2008). According to Levy et al. (2010) SR has "become embedded in the operational routines and practices of hundreds of large companies in multiple countries" (p. 89). As institutional theory emphasizes, social processes are characterized by stability and inertia, and an important focus of this theory is the explanation of why when something is institutionalized it is not likely to change (Zucker, 1977). Djelic and Sahlin-Andersson (2006) contend that "[i]nstitutional forces generally become taken for granted as the ... 'natural' way of being and doing" (p. 23). The analysis in this paper follows from these points to articulate the role played by different institutional actors and the structural conditions that engendered the conditions of possibility for this SR institution through the means of the GRI.

\subsection{The dynamics of institutionalization: the life-cycle of SR norms}

In their examination of the development of environmental reporting in the UK and Spain, Bebbington et al. (2012) draw on the notion of the "life cycle" of norms (Brunnee and Toope, 1997; Finnemore and Sikkink, 1998; Sunstein, 1996), "according to which norm influence can be depicted as a three-stage process that starts with the emergence of norms, characterised by the innovation of norm entrepreneurs, followed by diffusion leading to a 'tipping point' after which the norm cascades to reach a point at the end of the life cycle where norms are internalized and acquire a taken-for-granted quality" (Bebbington et al., 2012, p. 79). These authors studied the construction of normativity to capture the notion that the legitimacy of institutions rests on a set of conditions that can be contextual as well as internal to the institution itself.

Assuming that SR has reached a tipping point for MNCs (the evidence above makes this a sound working hypothesis), the lifecycle framing assumes that the pressure for compliance exists in the third stage of the life cycle of norms. At this stage, and once a tipping-point is attained, non-reporters feel a strong pressure to report and the activity in question rapidly cascades to converge with expectations to create a norm/institution. Indeed, once a norm has crystalized, it will reinforce itself by inscribing subsequent actions with the logics of the 
institutionalized orthodoxy. In our historical timeline, this process was attained by the ability of the GRI to emerge and to describe what SR should entail.

Before this crystallization of the norm, institutional entrepreneurship is necessary in the initial stages of the life cycle of norms. Relevant questions for this time period include who produces the innovations (and how they do this), how these innovations differ from existing norms and practices, and how new practices create new networks. Institutional entrepreneurs have been studied for the social reporting of a cooperative bank by Contrafatto et al. (2019), for environmental reporting in the UK and Spain by Bebbington et al. (2012) and for SR by Levy et al. (2010). The notion of institutional entrepreneurship is consistent with the argument that the different steps in institutional inscription are characterized by power, struggle and negotiation that involve multiple actors and their interests (Djelic and SahlinAndersson, 2006).

While acknowledging the importance of institutional entrepreneurs, this paper seeks to open up the landscape to consider more actors and processes in order to complement actorcentric approaches (Jepperson and Meyer, 2011) and temper the sometimes heroic and visionary (Aldrich, 2011) narratives that run the risk of creating an overly linear, functionalist and atomistic accounts of social processes (Hardy and Maguire, 2008). The notion of the lifecycle of norms seeks to do this by providing an explanation beyond the role of institutional actors (Aldrich, 2011; Djelic and Sahlin-Andersson, 2006; Hardy and Maguire, 2008; Hedmo et al., 2006; Strang and Soule, 1998). Specifically, this framing highlights that epistemic communities (i.e. informal networks of "professionals with recognized expertise and competence in a particular domain and an authoritative claim to policy-relevant knowledge within that domain" - see Haas, 1992, p. 3), carriers (who facilitate the transference of practices and ideas - see Sahlin and Wedlin, 2008), and the reporting organizations themselves (Bebbington et al.,2012) are also active norm producers (for more recent examples of this dynamic, see de Aquino et al., 2020 and Senn and Giordano-Spring, 2020).

Following this perspective, the next section presents an account of SR institutionalization, and introduces a broader scope of actors in this process. However, no matter the number of actors included in the analysis, the explanation would be incomplete without an account of how social processes are shaped by culture, norms and pre-existing institutions. In this regard, for institutional actors to prescribe, translate and edit SR norms, they require some form of authority that is always, as explained below, problematic and requires institutional support. Bebbington et al. (2012) contend that this support is provided by institutional conditions that constrain and enable choices (Brunnée and Toope, 2000). Those institutional conditions are the result of gradual historical processes (Berger and Luckmann, 1966; Bourdieu, 1977; Bourdieu and Wacquant, 1992) whose understanding requires paying attention to the origin of specific SR practices and beliefs. Following this approach, the subsequent sections will analyze the role of a broad scope of actors in the production of sustainability norms (Section 3) and the institutional conditions that provided support to this activity (Section 4).

\section{An array of institutional actors}

Hardy and Maguire (2008) contend that process-based institutional explanations need to provide an account punctuated by the participation of different actors. In order to do this, and following a constructivist understanding of regulation (Bebbington et al., 2012; Brunnée and Toope, 2000; Finnemore and Sikkink, 2001; Larrinaga and Senn, 2021), we analyze the role played by an array of actors in the production of SR norms. For analytic purposes (while noting that a clear-cut boundary cannot be drawn) the role of institutional entrepreneurs, epistemic communities, carriers and reporters in SR norms production will be presented separately below. 


\section{AAAJ}

34,9

\subsection{Institutional entrepreneurship}

GRI has been interpreted as an institutional entrepreneur (Brown et al., 2009; Levy et al.,2010), who was a political agent that had interests in particular institutional arrangements and who used various resources to transform reporting institutions to create SR. Levy et al. (2010) explain that GRI entrepreneurship involved launching a reporting initiative that soon achieved a high degree of approval by relevant actors and, particularly, a high degree of acceptation by large companies across the globe. These authors contend that GRI's innovation consisted in a skillful combination of strategies that included the development of GRI as an organization, the inscription of a network of relations with powerful actors and the construction of discourses (cf. building on existing discourses) that legitimized SR among multinational companies. Levy et al. (2010) use the Gramscian concept of hegemony to explain how the discursive and political structures determine the process of SR diffusion. Their thesis is that SR arrangements and compromises were based on the negotiation of discourses that were palatable for the dominant coalition, i.e. corporations. For example, through a win-win discourse of corporate social responsibility and emphasis in procedural issues (e.g., reporting principles), the GRI avoided the dangers of a confrontation with industry. Further Gramscian analyses (Spence, 2007; Archel et al., 2011) suggest that businesses and business organizations deployed their resources to inscribe a business case discourse that subverted the radical meaning that sustainable development and corporate social responsibility carried in the nineties and that increasingly marginalized approaches interested in more profound transformations of corporate governance.

The release of the first edition of the GRI guidelines in 1999 produced an immediate impact, with 44 companies issuing a sustainability report in 2000, according to the GRI databases, as well as a more permanent impact, with more than thirteen thousand organizations reporting in 2019. It is evident, therefore, that the issuance of the GRI reporting guidelines had an effect in SR practices. The GRI also codified different rules and expectations about SR that remain a dominant reference in the field, despite subsequent developments such as integrated and non-financial reporting. Prior to this point in time, other actors could also be observed playing an entrepreneurship role. Such is the case of the Association of Chartered Certified Accountants (ACCA hereafter) awards or reporting pioneers (Bebbington et al., 2012), and it is to these actors that attention now turns.

\subsection{Epistemic communities}

More than a decade elapsed between the publication of the Bruntland Report (UNWCED, 1987) and the first GRI sustainability reports being published. Milne and Gray (2013) note that the term sustainability was seldom used in the nineties in the context of corporate reporting and it could (on the face of it) be concluded that the nineties was a "lost" decade in terms of SR (Lamberton, 2005): this reading also accords with Levy et al. (2010). Our argument, however, is that an examination of the history of reporting prior to 1999 provides insight into the emergence of epistemic communities that were instrumental in the problematization of the interplay between accounting and social/ecological issues, the generation of new ideas about this relationship, and the design of new ways to influence corporate reporting practice.

A vigorous debate on how to account for the social and environmental impacts of organizations existed long before 1987 (see Bebbington, 2021). In the early seventies, the scope and nature of reporting expanded beyond financial information for shareholders to include social and ecological data for other users of accounts. The report of the Committee on Environmental Effects of Organizational Behavior of the American Accounting Association (1973), as well as the UK Corporate Report (Renshall, 1976), discussed the social and ecological implications of organizations, measurement and reporting issues and the duty to provide 
information for more than shareholders. Such was the climate at this time that most articles in the inaugural issue of Accounting, Organizations and Society (now one of the most influential academic journals in the accounting field) dealt in some way or another with social and environmental issues. Looking back, it is remarkable to read, in the very first page of this journal, Professor Hopwood (1976) affirming that:

social accounting, social reporting and social auditing may be embryonic (...) the awareness of ecological problems is drawing attention to the necessity of developing accounting systems which can report on an organization's use of scarce resources. (p. 1)

Epistemic communities (Haas, 1992, 2015), including academics and experts, engaged with corporations, stakeholders and policymakers in different areas, trying to influence practice, resulting in some seminal reporting innovations. For example, the value-added reporting, social audits and attempts to account for externalities were first experimented in the 1970s and into the 1980s (see Unerman et al., 2018 for a brief history). On the one hand, epistemic communities provided authoritative knowledge in attempts to make the value-added statement mandatory in the UK (Burchell et al., 1985) and France (in the form of the Bilan social - see Christophe and Bebbington, 1992). On the other hand, the seventies saw the emergence (still present in some form) of external social accounting/audits. These activities reflected the concern about the externalities of corporate practices and a critique of the corporate narratives of the straightforward benefits of company activities (Gray et al., 1987; Harte and Owen, 1987), and were most evident in accounts that contested the closure of coalmines in the United Kingdom (Cooper and Hopper, 1988).

At the end of the eighties a change, epitomized by the Brundtland Report, created an addition (and dedicated) focus on environmental concerns in policymaking and research communities. Rather than being an additive process, however, it would appear that a focus on the environment came at the detriment of the existing social accounting focus (Gray, 2002). Once again, epistemic communities provided advice and championed social and environmental reporting in the nineties. An early example was Gray (1990), a research commissioned by the ACCA in direct response to Pearce et al. (1989) (see Thomson, 2020). Two special issues of Accounting, Auditing and Accountability Journal (in 1991) and Accounting, Organizations and Society (1992, and for a discussion see Gray and Laughlin, 2012 and Parker, 2020) tried to address the accounting implications of including the environment and to some extent the emerging sustainable development agenda. Those ideas were developed symbiotically with other actors, such as ACCA, AccountAbility and the Fédération des Experts-Comptables Européens (FEE, now Accountancy Europe), who in combination produced reports on social and environmental accounting that supported the European Commission's (2001) work and also the GRI. A reporting conceptual framework, performance indicators, assurance or annual reporting are some of the framings elaborated and diffused by these epistemic communities which have become essential elements of SR practice. It is also relevant to note the fact that those epistemic communities spanned academic, professional and consultancy networks, thereby creating conditions for wide acceptability of their propositions.

In summary, this section highlights the importance that epistemic communities had in the generation of new ideas about social and environmental responsibility and reporting and in devising new strategies to intervene in the production of corporate reporting norms. However, such role also needs to be understood in interaction with the plurality of actors that were also involved in the pre-GRI pre-SR reporting context.

\subsection{Carriers}

The diffusion of reporting norms is facilitated by the transfer of practices and ideas about what constitutes "appropriate" SR and this is enabled by norm carriers (Sahlin and Wedlin, 2008).

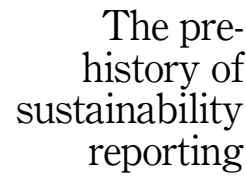

167 
AAAJ

34,9

168

Carriers play an active role in interpreting and editing SR norms as they develop across institutional fields (Czarniawska and Sevón, 1996). Carriers, such as consultants, auditors and professional and business associations monitored SR practice and encouraged certain forms of practice. Jacobsson and Sahlin-Andersson (2006) suggest that monitoring is a way through which institutional actors obtain authority to negotiate and set norms. One illustration of how carriers inscribed particular interpretations and institutional practices is provided by SR award schemes (which succeeded environmental reporting award schemes), led by the ACCA but followed by other national and international organizations such as the European Sustainability Reporting Association (ESRA) [3]. Regardless of whether or not the original intention of those organizations was to influence SR, the existence of reporting awards schemes was itself a driver for the initiation of reporting, as has been observed, for example, in the case of the Malaysian companies (Amran and Haniffa, 2011). Additionally, the benchmarking effect of awards seems to have played a crucial role in encouraging experimentation and in inscribing particular expectations about SR practice, such as having reports assured and reporting against targets (Bebbington et al., 2012).

Apart from reporting awards, carriers such as firms providing consultancy and assurance services also played a role (Etzion and Ferraro, 2010). Among them, large auditing firms have played a major role in SR as well as in the institutional configuration of GRI. An illustration is the influence of the triennial KPMG'S SR survey in encouraging specific reporting topics and providing a benchmark for reporting practices. The first version of this survey was published in 1993 and addressed environmental reporting. Subsequent editions were, arguably, setting the trends in the field: reporting against targets and verification featured prominently in the 1996 and 1999 survey reports; sustainability and SR in the 2002 survey report; environmental and SR was replaced by the label of corporate responsibility reporting in 2005; the role of investors relations was highlighted in 2008, and integrated reporting in 2011. It is our contention that while these reports reflected trends, they also created particular reporting practices. Milne et al. (2001), for example, provide an indication of the relevance of such surveys when they refer how the "1996 triennial KPMG survey of corporate environmental reporting placed New Zealand last among 13 OECD countries, a fact shocking enough to make prime-time television news at the time." This observation, and our point generally here, is that the role that ACCA, KPMG and other carriers have played in the inscription of particular SR norms is virtually non-existent in the literature (but see Bebbington et al., 2012) and relies on the recollection of those who were involved in these schemes and activities at this time (and hence our motivation to capture such information here).

In addition, carriers of reporting practices, with a special focus on capital markets, include the development of indexes such as the Dow Jones Sustainability Index and the FTSE4Good that were launched at about the same time as the GRI. Inclusion in these indexes was motivating for some companies and reporting quality increased the chances of inclusion (with the associated effects of joining and leaving these indexes generate - see Collison et al., 2009 and Martin Curran and Moran, 2007). In this way these indexes also carried expectations about SR, for example, in terms of the topics covered (Knoepfel, 2001), while also providing some visible rewards for those companies that excelled in the evolving reporting norms.

\subsection{Regulators and reporters}

A constructivist perspective of legal studies, focusing particularly on international law and transnational governance (see Bebbington et al., 2012, for a review of these ideas), is interested in the demarcation of what counts as the regulator, the regulatee and compliance. The previous discussion has illustrated how SR norms were produced by a plurality of actors in a soft law context. And yet, despite the soft nature of this regulation, governments still played a role (for example, in cases such as the bilan social in France - noted above) and the European 
Union EMAS (explored below). However, it is also important to appreciate that reporting companies also have a role in the development of norms.

In soft law, reporters are identified as having the ability to modify and edit SR norms, at least in two ways. On the one hand, some reporters have participated in the construction of SR via the GRI process and other initiatives. In a multi-stakeholder dialogue setting, organizations influence epistemic communities, carriers and governments: in this way they are active producers of reporting norms that, at the same time, shape their own reports. Furthermore, some reports (e.g. The Body Shop environmental reports) have been portrayed in the past as exemplars to be imitated by other companies (Azzone et al., 1997), further amplifying their authority to edit norms. On the other hand, companies that were active in social and environmental reporting prior to the birth of SR (Gray et al., 1995) had the power to devise, in a more or less deliberate way, what reporting practices and expectations could be realistic or even plausible/thinkable. For example, attempts to introduce norms on disclosure of externalities in the ACCA awards were unsuccessful (despite the awards being carriers of practice) and finally abandoned, given the lack of attention given by reporters. Bebbington et al. (2012) contend that reporters use their position to determine what parts of norms (do not) deserve compliance and in this manner actively shape reporting practices and expectations.

\section{Beyond authority: mechanisms for supporting SR norms}

Whereas Section 3 focused on agency, this section considers the institutional conditions that provide the support for institutional actors to prescribe, translate and edit SR norms. To reiterate, it is our contention that understanding the origin of specific SR practices and beliefs requires a consideration of how institutional arrangements either enabled or constrained agency (Brunnée and Toope, 2000). Institutional conditions are, in the first place, shaped by broader societal trends and beliefs about the functionality of SR. However, drawing on legal studies (Bebbington et al., 2012), and considering that the development of SR norms could be characterized as soft law, we study how the legitimacy of SR (i.e. the legitimacy of the norm itself, rather than the legitimacy of the actors), founded on elements that are internal to the own institution, paved the way for norm production (Bebbington et al., 2012).

\subsection{Societal context}

Professor Hopwood (1976, p. 1) contended that the (then) "current social, environmental and political developments [were] focusing increasing attention on the wider accountability of organizations." For example, workers and unions rights were legally advanced in the seventies, particularly with respect to participation in the organization and the provision of information and there were discussions about the reform of the enterprise to improve the conditions of work and allow the participation of workers in management (Robertson, 1976; Sudreau, 1976). Likewise, information addressed to the employees was regulated in countries such as France (through the previously discussed bilan social). Taken together these interests provided a core component of social reporting that latterly became linked to debates about corporate responsibility and which eventually was brought under the auspices of SR.

At the same time, the interest in ecological issues was emerging in the seventies, as epitomized by the debate around the limits to growth (Meadows et al., 1973). It took a little longer for these concerns to crystalize but they did in 1987 with the Brundtland Report, and in 1992 with the Rio Summit. By this time, environmental concerns started to infuse government thinking, reflecting a more longstanding concern articulated by NGOs and civil society. At the European level, the EU developed numerous strands of environmental policy, including instruments such as the European Eco-Management and Audit Scheme (EMAS hereafter) in 1993 that included plans to model the environmental impact of organizations

\section{The pre- history of sustainability reporting}


AAAJ

34,9

(Bebbington, 1993; Bebbington et al., 2001). What is apparent from this brief description is that the social context of business from the seventies to the nineties provided a fertile ground for the development of social and environmental reporting and the discourses that supported its development (for more depth, see Bebbington, 2021).

\subsection{Development of SR discourses}

The factors outlined above provided the context from which discourses emerged that supported the emergence of social accounting in the 1970s and environmental accounting in the 1980s. First, a discourse emerged to suggest that social and environmental reporting held the potential of empowering stakeholders and make corporations accountable for their impacts (Gray, 2002; Gray et al., 1987; Gray et al., 1996). Second, a narrative about the business case for social and environmental reporting also emerged (Azzone et al., 1997; Toms, 2002). However, more recently, different studies have elucidated that reporting did not deliver the promised economic benefits (Hahn and Kühnen, 2013; Husillos et al., 2011; Levy et al., 2010), nor produced the emergence of a new accountable and sustainable corporation (Archel et al., 2011; Cho et al., 2015; Dingwerth and Eichinger, 2010; Gray and Milne, 2004; Levy et al., 2010; Milne and Gray, 2013; Moneva et al., 2006; Tregidga et al., 2014). Indeed, for Gray (2010): "It is increasingly well-established in the literature that most business reporting on sustainability and most business representative activity around sustainability actually have little, if anything to do with sustainability" (p. 48).

We hypothesize that both the accountability and the business case discourse, despite their apparent contradiction, created similar dynamics. As reporting did not obviously create economic benefits, the formal aspects of SR were decoupled from financial returns. Likewise, reporting did not obviously enhance accountability, so SR was decoupled from sustainable development. In the presence of conflicting pressures, organizations are likely to adopt formal procedures that are decoupled from actual practice (Meyer and Rowan, 1977). In other words, the resilience and stability of SR derives from its decoupling not only from broader considerations of sustainability or from attempts to transform the enterprise, but also from financial returns. This explanation is consistent with Levy et al.'s (2010) ideas about how the GRI avoided conflicting logics, focusing on procedural matters. Our point here, however, is that these conflicting logics were already inherent in social and environmental accounting, the antecedent to SR, and already created institutional pressures leading to decoupling formal reporting practices from the bottom line.

Although the societal context and discourses of SR functionality confer exogenous institutional support for the production of reporting norms, we contend that understanding the SR institutionalization requires an examination of elements that are endogenous to the institution itself. With this argument we problematize the power of institutional actors (Jepperson and Meyer, 2011) and suggest, in keeping with institutional theory, the importance of examining the institution itself. For this endeavor we draw on Bebbington et al. (2012) to examine three elements of the SR institution: (1) how analogies with previous institutions (e.g. financial reporting) enabled the verbalization and validation of SR; (2) how congruence between SR and previous similar practices and conventions (the existence of non-financial reporting precedents, such as environmental reporting) served as archetypes and stimulated SR; and (3) how the problems arising from an inadequate design of SR technical aspects constrained the possibilities of SR.

\subsection{Analogies}

SR studies taking an actor-centric representation of GRI institutional entrepreneurship (Levy et al., 2010; Etzion and Ferraro, 2010) have recognized that its analogy with the Financial Accounting Standards Board was an important legitimation strategy for GRI. Indeed, the 
focus of these studies on standard setting bodies is a consequence of their actor-centric interests and framings. However, the exploration of ideas and practices as analogies, rather than actors and specific organizations, provides insights into how some templates/formal structures are available (in this case in financial reporting) that are easily recognized and approved when applied to a different set of practices (SR in this case), thereby providing it with legitimacy (Douglas, 1986). Some of the financial reporting analogies that facilitated the validation and institutionalization of SR concern ideas such as non-financial reporting, conceptual underpinning of the financial reporting framework (such as considerations of qualitative characteristics of information and the establishment of the entity, and hence associated entity boundaries), performance indicators and reporting assurance.

First, the very idea of non-financial reporting is a response to the existence of financial reporting. It is worth considering how the SR emancipated itself from the corporate annual report. Up until the early nineties, social and environmental disclosures were usually made in sections of the annual report document, which was published in paper format. In this context, Gray et al. (1995, p. 69) explained that "the annual report is considered widely to be a major formal document which acts as a significant presentation by an organization and has a major influence on perceptions of it." Therefore, it was considered that if companies made social and environmental disclosures in this document was because management and stakeholders considered them as important. Stand-alone social and/or environmental reports were unusual at his time (with the exception of employee reports in the late 1970s and early 1980s; Gray et al., 1987), but they grew in number in the eighties and the nineties. It should be noted that the SR (and environmental equivalent) was described for some time (at least while they were still published in paper format) as "stand-alone" reports to differentiate them from the social and environmental disclosures made as part of the corporate annual report.

Second, the financial reporting framework also provided a model for the design of a SR conceptual framework, as evidenced in the preface of the 2002 GRI guidelines (GRI, 2002, p. 1): "GRI recognises that developing a globally accepted reporting framework is a long-term endeavour. In comparison, financial reporting is well over half a century old and still evolving amidst increasing public attention and scrutiny." This analogy was not an original thought. Rather, the GRI borrowed it from other organizations, such as AccountAbility and the FEE (Moneva et al., 2006). This suggests that a focus on the explanatory power of a broader number of institutional actors will highlight the broad basis of these types of influences. FEE, for example, was active in this domain from the nineties, working with European institutions, the International Accounting Standards Board, academics and other actors interested in environmental reporting. The mutual influences between actors in the SR space and their collective agency is also observable from a FEE publication in 1999 (a document entitled Towards a Generally Accepted Framework for Environmental Reporting, FEE 1999) that was subsequently incorporated in the same year into the "General Reporting Principles" section of the GRI guidelines (Collison and Slomp, 2000).

Third, the specific issues that should be included in every SR were validated through the analogy with performance indicators. Borrowed from operations research and systems theory, the notion of performance indicators acquired status in management accounting in the seventies and the eighties, as it became apparent that business should internally manage not only costs but also quality and other non-financial issues (Larrinaga, 2020; Otley and Berry, 1980). Environmental management systems (e.g., EMAS and the ISO group of standards) imported, in turn, the notion that different performance indicators should be addressed, rather than one single target (Henri and Journeault, 2010). Consequently, the GRI had a clear model to follow when it "coded" social and environmental issues into performance indicators that should draw managers' attention. The problematic nature of this translation, as evidenced by the difficulty of translating some social issues (e.g., human rights) into

\section{The pre- history of sustainability reporting}


AAAJ

34,9

assessable indicators, did not prevent the recognition of the idea of performance indicators by corporate managers who were already familiar with their use.

Finally, one key element of the SR edifice has been the aspiration to overcome reliability problems through the provision of assurance. This notion points toward a further analogy with financial reporting - that of auditing. Despite how difficult the assurance of social and environmental issues has proven to be and, therefore, how contested this translation is (O'Dwyer and Owen, 2005; O'Dwyer, 2011; O'Dwyer et al., 2011), the fact that many providers of assurance services are the large international auditing firms strengthens this analogy (Larrinaga et al., 2020).

This account suggests that the linking of previously acceptable ideas/practices facilitated SR legitimacy by providing analogies for elements of SR practice. By presenting SR as something that conforms to existing structures, sharing notions and norms (often arising from a financial reporting framework and that are familiar and legitimate in the field of corporate reporting), SR was recognized and "approved of" by corporate actors, NGOs, government officials and other actors who supported the project.

\subsection{Previous similar practice: environmental reporting}

A further direct source of legitimacy for SR was the previous practice of environmental reporting. Bebbington et al. (2012) contend that the legitimacy of a norm "depends upon its congruence with previous similar practices and conventions that create relatively stable patterns of expectations or shared understandings (i.e. there is an appreciation of the reasons why these institutions are necessary)" (p. 86). In this respect, SR did not appear ex novo, but this activity was built on the previous practice of environmental reporting.

Some contextual information about environmental reporting provides an understanding of the extent to which SR was, at least partially, a metamorphosis of environmental reporting. Environmental reporting was emerging as a practice in the 1980s, but it was the European Commission policy of implementing market mechanisms to encourage companies to deal with their environmental problems that arguably stimulated the growth of reporting in the early nineties. The European Union policy with regard to the environment (and the Fifth Action Plan on the environment "Towards Sustainability," in particular) had the aim of pushing industry to disclose more information about its environmental performance and externalities (European Union, 1993), and this played an influential role in environmental reporting (Hillary, 1995). This objective materialized in 1991, in the form of European plans to make environmental management systems compulsory for large industrial companies, including environmental audits and an annual environmental statement, verified by external independent parties (Bade, 1991). The final 1993 version of the EMAS made the registration of companies to the scheme voluntary. Nevertheless, the fact that compulsory reporting had been considered by policy makers validated the discussion and the practice of environmental reporting. In this respect, by the end of 1998 more than 2,000 European industrial sites were registered under EMAS, with the prerequisite of publishing a verified environmental statement. This activity stimulated the discussion about corporate social responsibility reporting, the growth of a reporting assurance industry and a community of scholar investigating environmental reporting, beyond the discipline of accounting (see, e.g., Kolk, 1999). All these elements point towards the complex interplay between actors and structures in the institutionalization of SR that is the main thesis of this paper.

When GRI devised SR, it had a clear model to follow in stand-alone environmental reporting. Indeed, the first version of the GRI guidelines (1999) had a predominately environmental focus, in clear connection with the previous practice that emerged from EMAS, the ACCA awards scheme and recommendations from epistemic communities such 
as FEE (Larrinaga, 2001). SR diffusion was further facilitated by the previous experience in many large companies that had allocated resources to environmental reporting. In fact, for many industrial companies, SR simply replaced environmental reporting and only gradually included social disclosures (Kolk, 2003). In this regard, SR could be described as a metamorphosis of environmental reporting, rather than as a wholesale innovation. This metamorphosis was also connected with the critique raised by epistemic communities about the absence of the social in environmental reports (see, e.g., Mathews, 1997).

In summary, although SR can be seen as an innovation dating from 1999, with the issuance of the GRI reporting guidelines, an examination of the previous environmental reporting practice suggests that this activity served not only as a model of what might be in reports, but also constituted an organizational routine that could be transferred to a new setting and transformed into SR, thereby enabling the legitimacy and the convergence of SR practices and expectations around a set of norms. This does not detract from the importance of the GRI codification of the prior expectations. Rather, points of continuity from environmental reporting underpinned aspects of the success of SR.

\subsection{Design of $S R$}

The final institutional condition examined here focuses on the technical details of SR and how the translation from financial reporting of some of those elements impeded a precise and clear design for reports. The analysis of this element is inspired not only by the idea that the precise and clear technical design of norms for the achievement of the intended purposes is an important element of normativity (Brunnée and Toope, 2000; Franck, 1990), but also by MacKenzie (2009) who called for "matters of apparent detail that in fact play critical roles" (p. 453) to be brought to light. The intrinsic problems in attempts to translate sustainable development to corporate reports and the organizational context have already been discussed in the literature (Bebbington and Larrinaga, 2014; Gray, 2006, 2010; Milne and Gray, 2013; Moneva et al., 2006). A non-comprehensive list of such concerns could include the definition of sustainability indicators and the (lack of) consideration of sustainability challenges (while noting that assurance and boundaries could also be pertinent candidates for such an analysis).

A difficulty inherent to SR relates to the different dimensions of sustainable development which have to be translated (e.g., following the triple-bottom-line logic) and how these dimensions, and especially social aspects, are not easily amenable to quantifiable indicators (e.g., human rights). These difficulties produce a lack of integration and comparability that hinders the ability of SR to achieve the multiple goals (performance enhancement and accountability) ascribed to it. Furthermore, the (macro) notion of sustainable development resists a significant translation into the (micro) organizational level of resolution (Gray, 2010; Bebbington and Larrinaga, 2014). These difficulties are evidenced by the lack of progress that the GRI has made since 2002 in terms of the design of new indicators and indicators that connect organizational performance with sustainable development, compared to the innovation that took place in the nineties (Gray and Laughlin, 2012).

It has been argued that SR does not address the most critical challenges for sustainable development (Bebbington and Larrinaga, 2014; Gray, 2006). Apart from climate change, two critical sustainability challenges - biodiversity loss and the nitrogen cycle (Rockström $e$ t al., 2009) - are not being addressed in SR. Agriculture, for example, the most relevant industry in terms of impacts on biodiversity and the nitrogen cycle, features as a rather marginal industry in terms of SR with some reporters being highly innovative (such as Unilever) but it being by no means a mainstream activity. It was not until the Sustainable Development Goals started to make their presence felt in accounting scholarship that some of these gaps and scale issues have been revisited (see Bebbington and Unerman, 2018, 2020).

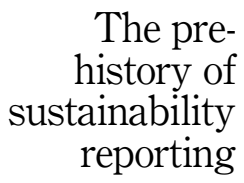

173 
AAAJ 34,9

The academic accounting critique of SR underlines the dangers of this institutional design, since in the view of Milne and Gray (2013) it "has been instrumental in expanding and shaping organizational practice, it has also become dangerously confused with advancing a just and sustainable world" (p. 24). Notwithstanding the verisimilitude of such explanation, institutional theorists provide a different angle to understand how the trajectories of institutions do not reflect the intentions of all institutional actors but are the outcome of strategic choices and compromises. Levy et al. (2010) contend that the GRI could have materialized in something different than the initial intentions of some of the key actors. Indeed, this is our argument in this section, with the observation that design and further structural mechanisms constrain/enable different institutional trajectories. Further, this activity has evolved into a corporate convention that organizations need to comply with to show conformity with social values or imitate to reduce uncertainty. Reporting is often decoupled from corporate activities, in such a way that is not delivering any of the promised objectives, neither in terms of yielding benefits for companies and shareholders, nor in terms of empowering stakeholders and making corporations accountable for their social and environmental impacts.

In summary, this section explored how analogies, environmental reporting and design constrain and enable different SR trajectories. More specifically, analogies with financial reporting and the previous practice of environmental reporting provided legitimacy to SR, while design problems limited the achievement of SR's aims. This section has also illustrated how structural mechanisms are intertwined with each other and with the different actors explored in Section 3.

\section{Concluding comments}

SR has become an institutionalized practice for large companies across the globe and is sustained by a number of entities and (latterly) by formal legal requirements for non-financial reporting. This is a remarkable achievement for a set of practices that are only 20 years old in a formal sense (if we date their emergence to the influence of the founding of the GRI in 1999). This paper takes the importance of the GRI as given and seeks to provide an additional layer of reflection on SR practices by examining the period before 1999 using a constructivist understanding of regulation introduced to the accounting literature by Bebbington et al. (2012). The idea of a lifecycle of norms highlights the contribution of a combination of actors (namely, epistemic communities, carriers, regulators and reporters) that were present in the reporting landscape during the 1990s. In addition, a conducive institutional setting (in terms of societal context, analogies with financial reporting, and the presence of environmental reporting) developed during that time period. These aspects are part of the history of SR and have not been written about extensively in the literature: the passage of time has also made these aspects more salient with the benefit of hindsight.

While understanding the past is a valid aspiration in and of itself, there are also more practical reasons for this focus. For example, more detailed study of carriers, reporters and the design of SR norms is needed to illuminate the specific trajectories of SR and, more specifically, the reasons why it has not achieved its original purposes of making corporations accountable for their social and environmental impacts and empowering stakeholders. In this regard, despite the recent regulation of SR in some jurisdictions, the exploration carried out in this paper suggests that this activity remains unstable for two reasons: (1) the agency of a plurality of institutional actors who elaborate and edit norms in a soft-law regulation context, such as the one that characterizes SR; and (2) the instability of the notion of sustainable development makes the design of sustainability indicators inherently contestable. These potential sources of limitation are also the point of departure for both new practices and require renewed academic inquiry. 
At the same time, at the close of 2020 there are signs that the landscape in which SR exists is poised to undergo further evolution, creating further opportunities to exploit the ideas developed in this paper to make sense of current SR trajectories. For example, the Sustainability Accounting Standards Board (SASB) and the International Integrated Reporting Council (IIRC) are to merge into the "Value Reporting Foundation," with the stated aim of creating for investors a reporting framework that will enhance sustainability performance of corporations. While not formally part of the new Foundation, the GRI and other reporting bodies (such as the Climate Disclosure Standards Board) are anticipated to collaborate to develop SR along this trajectory. In the terms used in this paper, it would appear that SR is poised for evolution with new carriers of the ideas behind SR as well as potentially new SR design norms emerging. Equally of interest, is the consultation that the IFRS Foundation launched in September 2020 (IFRS Foundation, 2020) about the role that it could play in developing a Sustainability Standards Board alongside its existing corporate reporting functions. The basis for this proposition is drawn from their existing expertise and experience of reporting in general, echoing the themes of epistemic communities and carriers of practices highlighted during the evolution of SR in the 1990s. It would seem, therefore, that a closer examination of the precedents of SR institutionalization might be useful in understanding the changes that are likely to come in the future.

\section{Notes}

1. The levels of reporting found in KPMG are consistent with those found in the literature (see Junior et al., 2014). Furthermore, the literature generally relies on KPMG figures to describe SR (Simnett et al., 2009; Marquis et al., 2016).

2. According to GRI databases, the number of worldwide organizations publishing sustainability reports rose from an average of 82 between 1999 and 2002 to around 6,000 in 2015. The annual growth rate gradually declined in this period: 167\% (average for the period 1999-2002), 40\% (20032010), 27\% (2011-2013) and 7\% (2014-2015).

3. The ACCA reporting award scheme commenced in 1991 with the inaugural competition attracting eight standalone report entries. From this small beginning the awards grew, reaching some 50 entries in 1996 (made up of 32 United Kingdom and 18 European organisations). At this stage, the competition also widened its scope to include social and ethical reports as well as evolving to have more regionally orientated awards schemes (in both individual countries and in terms of a European wide award). Moreover, in 2001 the awards were split into three categories: environmental, social and sustainability reporting. Eventually, and with more reports being produced but less being entered into awards schemes the ACCA sponsored process in the United Kingdom concluded around 2008 but awards schemes were in place longer elsewhere in the world where reporting is still developing (for example, the ACCA Pakistan reporting awards scheme that wrapped up in 2012). Roger Adams (the technical director of the ACCA) was a carrier of reporting practices over this time, as was the ACCA itself.

\section{References}

Aldrich, H.E. (2011), "Heroes, villains, and fools: institutional entrepreneurship, NOT institutional entrepreneurs", Entrepreneurship Research Journal, Vol. 1 No. 2, pp. 1-4.

American Accounting Association (1973), "Report of committee on environmental effects of organizational behavior", The Accounting Review, Vol. 48, pp. 75-119.

Amran, A. and Haniffa, R. (2011), "Evidence in development of sustainability reporting: a case of a developing country", Business Strategy and the Environment, Vol. 20 No. 3, pp. 141-156.

Archel, P., Husillos, J. and Spence, C. (2011), "The institutionalisation of unaccountability: loading the dice of Corporate Social Responsibility discourse", Accounting, Organizations and Society, Vol. 36 No. 6, pp. 327-343.

\section{The pre- history of sustainability reporting}


AAAJ 34,9
Azzone, G., Brophy, M., Noci, G., Welford, R. and Young, W. (1997), "A stakeholders' view of environmental reporting”, Long Range Planning, Vol. 30 No. 5, pp. 699-709.

Bade, R. (1991), “A city perspective on environmental audits", Managerial Auditing Journal, Vol. 6 No. 5, pp. 26-30.

Bebbington, J. (1993), "The EC fifth action plan: towards sustainability", Social and Environmental Accountability Journal, Vol. 13 No. 1, pp. 9-11.

Bebbington, J. (2021), "Foundations of environmental accounting", in Bebbington, J., Larrinaga, C., O'Dwyer, B. and Thomson, I. (Eds), Routledge Handbook of Environmental Accounting, Routledge, Abingdon, pp. 17-28.

Bebbington, J. and Larrinaga, C. (2014), "Accounting and sustainable development: an exploration”, Accounting, Organizations and Society, Vol. 39 No. 6, pp. 395-413.

Bebbington, J. and Unerman, J. (2018), "Achieving the united nations sustainable development goals: an enabling role of accounting research", Accounting, Auditing \& Accountability Journal, Vol. 31 No. 1, pp. 2-24.

Bebbington, J. and Unerman, J. (2020), “Advancing research into accounting and the UN sustainable development goals", Accounting, Auditing \& Accountability Journal, Vol. 33 No. 7, pp. 1657-1670.

Bebbington, J., Gray, R., Hibbit, C. and Kirk, E. (2001), "Full cost accounting: an agenda for action", ACCA Research Report, London, Vol. 73.

Bebbington, J., Kirk, E.A. and Larrinaga, C. (2012), "The Production of Normativity: a comparison of reporting regimes in Spain and the UK”, Accounting, Organizations and Society, Vol. 37 No. 2, pp. 78-94.

Berger, P. and Luckmann, T. (1966), The Social Construction of Reality, Amorrortu Editores, Buenos Aires.

Birkinshaw, J., Hamel, G. and Mol, M.J. (2008), "Management innovation”, Academy of Management Review, Vol. 33 No. 4, pp. 825-845.

Bourdieu, P. (1977), Outline of a Theory of Practice, Cambridge University Press, Cambridge.

Bourdieu, P. and Wacquant, L.J.D. (1992), An Invitation to Reflexive Sociology, The University of Chicago, Chicago.

Brown, H.S., de Jong, M. and Lessidrenska, T. (2009), "The rise of the global reporting initiative: a case of institutional entrepreneurship”, Environmental Politics, Vol. 18 No. 2, pp. 182-200.

Brunnée, J. and Toope, S.J. (2000), "International law and constructivism: elements of an interactional theory of international law", Columbia Journal of Transnational Law, Vol. 39, pp. 19-74.

Brunnee, J. and Toope, S.J. (1997), "Environmental security and freshwater resources: ecosystem regime building", The American Journal of International Law, Vol. 91, pp. 26-59.

Burchell, S., Clubb, C. and Hopwood, A.G. (1985), "Accounting in its social context: towards a history of value added in the United Kingdom", Accounting, Organizations and Society, Vol. 10 No. 4, pp. 381-413.

Cho, C.H., Laine, M., Roberts, R.W. and Rodrigue, M. (2015), "Organized hypocrite, organizational façades, and sustainability reporting”, Accounting, Organizations and Society, Vol. 40, pp. 78-94.

Christophe, B. and Bebbington, J. (1992), "The French Bilan social-a pragmatic model for the development of accounting for the environment? A research note", The British Accounting Review, Vol. 24 No. 3, pp. 281-290.

Collison, D. and Slomp, S. (2000), "Environmental accounting, auditing and reporting in Europe: the role of FEE", European Accounting Review, Vol. 9, pp. 111-129.

Collison, D., Cobb, G., Power, D. and Stevenson, L. (2009), "FTSE4Good: exploring its implications for corporate conduct”, Accounting, Auditing \& Accountability Journal, Vol. 22 No. 1, pp. 35-58. 
Contrafatto, M., Costa, E. and Pesci, C. (2019), "Examining the dynamics of SER evolution: an institutional understanding", Accounting, Auditing andamp; Accountability Journal, Vol. 32 No. 6, pp. 1771-1800.

Cooper, D.J. and Hopper, T. (1988), Debating Coal Closures. Economic Calculation in the Coal Dispute 1984-5, Cambridge University Press, Cambridge.

Czarniawska, B. and Sevón, G. (1996), Translating Organizational Change, De Gruyter, Berlin.

de Aquino, A., Lino, A., Cardoso, R. and Grossi, G. (2020), "Legitimating the standard-setter of public sector accounting reforms", Public Money and Management, Vol. 40 No. 7, pp. 499-508.

DiMaggio, P. and Powell, W. (1983), "The iron cage revisited - institutional isomorphism and collective rationality in organizational fields", American Sociological Review, Vol. 48 No. 2, pp. 147-160.

Dingwerth, K. and Eichinger, M. (2010), "Tamed transparency: how information disclosure under the global reporting initiative fails to empower", Global Environmental Politics, Vol. 10 No. 3, pp. 74-96.

Djelic, M.L. and Sahlin-Andersson, K. (2006), "Introduction: a world of governance: the rise of transnational regulation", in Djelic, M.L. and Sahlin-Andersson, K. (Eds), Transnational Governance: Institutional Dynamics of Regulation, Cambridge University Press, Cambridge, pp. 1-28.

Douglas, M. (1986), How Institutions Think, Syracuse University Press, New York, NY.

Ehnert, I., Parsa, S., Roper, I., Wagner, M. and Muller-Camen, M. (2016), "Reporting on sustainability and HRM: a comparative study of sustainability reporting practices by the world's largest companies", The International Journal of Human Resource Management, Vol. 27 No. 1, pp. 88-108.

Etzion, D. and Ferraro, F. (2010), "The role of analogy in the institutionalization of sustainability reporting”, Organization Science, Vol. 21 No. 5, pp. 1092-1107.

European Commission (2001), "Commission Recommendation of 30 May 2001 on the recognition, measurement and disclosure of environmental issues in the annual accounts and annual reports of companies", Official Journal of the European Communities.

European Union (1993), "A European Community programme of policy and action in relation to the environment and sustainable development", Official Journal of the European Communities, Vol. C138.

Finnemore, M. and Sikkink, K. (1998), "International norm dynamics and political change", International Organization, Vol. 52 No. 4, pp. 887-917.

Finnemore, M. and Sikkink, K. (2001), "Taking stock: the constructivist research program in international relations and comparative politics", Annual Review of Political Science, Vol. 4 No. 1, pp. 391-416.

Franck, T.M. (1990), The Power of Legitimacy Among Nations, Oxford University Press, Oxford.

Gray, R. (1990), The Greening of Accountancy: The Profession after Pearce, ACCA, London.

Gray, R. (2002), "The social accounting project and accounting organizations and society privileging engagement, imaginings, new accountings and pragmatism over critique?", Accounting, Organizations and Society, Vol. 27 No. 7, pp. 687-708.

Gray, R. (2006), "Social, environmental and sustainability reporting and organisational value creation?: whose value? Whose creation?", Accounting, Auditing \& Accountability Journal, Vol. 19 No. 6, pp. 793-819.

Gray, R. (2010), "Is accounting for sustainability actually accounting for sustainability. . .and how would we know? An exploration of narratives of organisations and the planet", Accounting, Organizations and Society, Vol. 35 No. 1, pp. 47-62.

Gray, R. and Laughlin, R. (2012), "It was 20 years ago today: sgt pepper, accounting, auditing andAccountability journal, green accounting and the blue meanies", Accounting, Auditing and Accountability Journal, Vol. 25 No. 2, pp. 228-255. 
AAAJ 34,9

Gray, R. and Milne, M. (2004), "Towards reporting on the triple bottom line: mirages, methods and myths", in Henriques, A. (Ed.), Triple Bottom Line: Does it All Add Up?: Assessing the Sustainability of Business and CSR, Earthscan Publications, London.

Gray, R., Owen, D. and Maunders, K. (1987), Corporate Social Reporting: Accountaing and Accountability, Prentice-Hall International, London.

Gray, R., Kouhy, R. and Lavers, S. (1995), "Corporate social and environmental reporting: a review of the literature and a longitudinal study of UK disclosure", Accounting, Auditing \& Accountability Journal, Vol. 8 No. 2, p. 47.

Gray, R., Owen, D.L. and Adams, C.A. (1996), Accounting and Accountability: Changes and Challenges in Corporate Social and Environmental Reporting, Prentice Hall, London.

GRI (2002), Sustainability Reporting Guidelines, Global Reporting Initiative, Boston.

Haas, P. (1992), "Introduction: epistemic communities in international policy coordination", International Organization, Vol. 46, pp. 1-35.

Haas, P.M. (2015), Epistemic Communities, Constructivism, and International Environmental Politics, Routledge, London.

Hahn, R. and Kühnen, M. (2013), "Determinants of sustainability reporting: a review of results, trends, theory, and opportunities in an expanding field of research", Journal of Cleaner Production, Vol. 59, pp. 5-21.

Hardy, C. and Maguire, S. (2008), "Institutional entrepreneurship", in Greenwood, R., Oliver, C., Suddaby, R. and Sahlin, K. (Eds), The SAGE Handbook of Organizational Institutionalism, SAGE, pp. 198-218.

Harte, G.F. and Owen, D.L. (1987), "Fighting de-industrialisation: the role of local government social audits", Accounting, Organizations and Society, Vol. 12 No. 2, pp. 123-141.

Hedmo, T., Sahlin-Andersson, K. and Wedlin, L. (2006), "The emergence of a European regulatory field of management education", in Djelic, M.L. and Sahlin-Andersson, K. (Eds), Transnational Governance: Institutional Dynamics of Regulation, Cambridge University Press, Cambridge, pp. 308-328.

Henri, J.F. and Journeault, M. (2010), "Eco-control: the influence of management control systems on environmental and economic performance", Accounting, Organizations and Society, Vol. 35 No. 1 , pp. 63-80.

Hillary, R. (1995), "Environmental reporting requirements under the EU: eco-management and audit scheme (EMAS)", Environmentalist, Vol. 15 No. 4, pp. 293-299.

Hopwood, A.G. (1976), "Editorial”, Accounting, Organizations and Society, Vol. 1 No. 1, pp. 1-4.

Husillos, J., Larrinaga, C. and Álvarez, M.J. (2011), "The emergence of triple bottom line reporting in Spain”, Revista Española de Financiación y Contabilidad, Vol. 60 No. 150, pp. 195-219.

IFRS Foundation (2020), Consultation Paper on Sustainability Reporting, IFRS Foundation, London.

Jacobsson, B. and Sahlin-Andersson, K. (2006), "Dynamics of soft regulations", in Djelic, M.-L. and Sahlin-Andersson, K. (Eds), Transnational Governance: Institutional Dynamics of Regulation, Cambridge University Press, Cambridge, pp. 247-265.

Jepperson, R. and Meyer, J.W. (2011), "Multiple levels of analysis and the limitations of methodological individualisms", Sociological Theory, Vol. 29 No. 1, pp. 54-73.

Junior, R.M., Best, P.J. and Cotter, J. (2014), "Sustainability reporting and assurance: a historical analysis on a world-wide phenomenon”, Journal of Business Ethics, Vol. 120 No. 1, pp. 1-11.

Knoepfel, I. (2001), "Dow Jones sustainability group Index: a global benchmark for corporate sustainability", Corporate Environmental Strategy, Vol. 8 No. 1, pp. 6-15.

Kolk, A. (1999), "Evaluating corporate environmental reporting", Business Strategy and the Environment, Vol. 8 No. 4, pp. 225-237. 
Kolk, A. (2003), "Trends in sustainability reporting by the fortune global 250", Business Strategy and the Environment, Vol. 12 No. 5, pp. 279-291.

KPMG (2011), KPMG International Survey of Corporate Responsibility Reporting 2011, KPMG, Amsterdam.

KPMG (2013), The KPMG Survey of Corporate Responsibility Reporting 2013, KPMG, Amsterdam.

KPMG (2015), Currents of Change. The KPMG Survey of Corporate Responsibility Reporting 2015, KPMG, Amsterdam.

KPMG (2017), The Road Ahead. The KPMG Survey of Corporate Responsibility Reporting 2017, KPMG, Amsterdam.

KPMG (2020), The Time has Come. The KPMG Survey of Sustainability Reporting 2020, KPMG, Amsterdam.

Lamberton, G. (2005), "Sustainability accounting - a brief history and conceptual framework", Accounting Forum, Vol. 29 No. 1, pp. 7-26.

Larrinaga, C. (2001), "The GRI sustainability reporting guidelines: a review of current practice”, Social and Environmental Accounting Journal, Vol. 21, pp. 1-4.

Larrinaga, C. (2020), “The world for which we account': systems thinking in rob gray's works”, Social and Environmental Accountability Journal, Vol. 40 No. 3, pp. 186-190.

Larrinaga, C. and Senn, J. (2021), "Norm development in environmental reporting", in Bebbington, J., Larrinaga, C., O'Dwyer, B. and Thomson, I. (Eds), Routledge Handbook of Environmental Accounting, Routledge, pp. 137-150.

Larrinaga, C., Rossi, A., Luque-Vilchez, M. and Núñez-Nickel, M. (2020), "Institutionalization of the contents of sustainability assurance services: a comparison between Italy and United States", Journal of Business Ethics, Vol. 163 No. 1, pp. 67-83.

Levy, D.L., Szejnwald Brown, H. and de Jong, M. (2010), "The contested politics of corporate governance: the case of the global reporting initiative", Business and Society, Vol. 49 No. 1, pp. 88-115.

Lieberman, M.B. and Asaba, S. (2006), "Why do firms imitate each other?", Academy of Management Review, Vol. 31 No. 2, pp. 366-385.

MacKenzie, D. (2009), "Making things the same: gases, emission rights and the politics of carbon markets", Accounting, Organizations and Society, Vol. 34 Nos 3-4, pp. 440-455.

Marquis, C., Toffel, M.W. and Zhou, Y. (2016), "Scrutiny, norms, and selective disclosure: a global study of greenwashing", Organization Science, Vol. 27 No. 2, pp. 483-504.

Martin Curran, M. and Moran, D. (2007), "Impact of the FTSE4Good Index on firm price: an event study", Journal of Environmental Management, Vol. 82 No. 4, pp. 529-537.

Mathews, M.R. (1997), "Twenty-five years of social and environmental accounting research: is there a silver jubillee to celebrate?”, Accounting, Auditing \& Accountability Journal, Vol. 10 No. 4, pp. 481-531.

Meadows, D., Meadows, D., Randers, J. and Behrens, W. (1973), Limits to Growth. A Report to the Club of Rome, Universe Books, New York.

Meyer, J.W. and Rowan, B. (1977), "Institutionalized organizations - formal-structure as myth and ceremony", American Journal of Sociology, Vol. 83 No. 2, pp. 340-363.

Milne, M. and Gray, R. (2013), "W(h)ither ecology? The triple bottom line, the global reporting initiative, and corporate sustainability reporting", Journal of Business Ethics, Vol. 118 No. 1, pp. 13-29.

Milne, M., Owen, D.L. and Tilt, C.A. (2001), "Corporate environmental reporting: are New Zealand companies bieng left behind?", University of Auckland Bsuiness Review, Vol. 3 No. 2, pp. 24-36.

Moneva, J.M., Archel, P. and Correa, C. (2006), "GRI and the camouflaging of corporate unsustainability”, Accounting Forum, Vol. 30 No. 2, pp. 121-137. 
AAAJ 34,9
O’Dwyer, B. and Owen, D.L. (2005), "Assurance statement practice in environmental, social and sustainability reporting: a critical evaluation", The British Accounting Review, Vol. 37 No. 2, pp. 205-229.

Otley, D.T. and Berry, A.J. (1980), "Control, organisation and accounting”, Accounting, Organizations and Society, Vol. 5 No. 2, pp. 231-244.

O'Dwyer, B. (2011), "The case of sustainability assurance: constructing a new assurance service*", Contemporary Accounting Research, Vol. 28 No. 4, pp. 1230-1266.

O'Dwyer, B., Owen, D. and Unerman, J. (2011), "Seeking legitimacy for new assurance forms: the case of assurance on sustainability reporting", Accounting, Organizations and Society, Vol. 36 No. 1, pp. 31-52.

Parker, L.D. (2020), "Sailing the big blue boat: rob Gray and the blue meanies", Social and Environmental Accountability Journal, Vol. 40 No. 3, pp. 175-80.

Pearce, D., Markandya, A. and Barbier, E.B. (1989), Blueprint for a Green Economy, Earthscan, London.

Renshall, J.M. (1976), "Changing perceptions behind the corporate report", Accounting, Organizations and Society, Vol. 1 No. 1, pp. 105-109.

Rinaldi, L., Unerman, J. and Tilt, C. (2014), "The role of stkeholder engagement and dialogue within the sustainability accounting and reporting process", in Unerman, J., O'Dwyer, B. and Bebbington, J. (Eds), Sustainability Accounting and Accountability, Routledge, Oxon, pp. 86-107.

Robertson, J. (1976), "When the name of the game is changing, How do we keep the score?", Accounting, Organizations and Society, Vol. 1 No. 1, pp. 91-95.

Rockström, J., Steffen, W., Noone, K., Persson, A., Chapin, F.S., Lambin, E.F., Lenton, T.M., Scheffer, M., Folke, C., Schellnhuber, H.J., Nykvist, B., de Wit, C.A., Hughes, T., van der Leeuw, S., Rodhe, H., Sorlin, S., Snyder, P.K., Costanza, R., Svedin, U., Falkenmark, M., Karlberg, L., Corell, R.W., Fabry, V.J., Hansen, J., Walker, B., Liverman, D., Richardson, K., Crutzen, P. and Foley, J.A. (2009), "A safe operating space for humanity", Nature, Vol. 461 No. 7263, pp. 472-475.

Sahlin, K. and Wedlin, L. (2008), "Circulating ideas: imitation, translation and editing", in Greenwood, R., Oliver, C., Suddaby, R. and Sahlin, K. (Eds), The SAGE Handbook of Organizational Institutionalism, SAGE, pp. 218-242.

Scott, W.R. (2008), Institutions and Organizations, Sage, Thousand Oaks.

Senn, J. and Giordano-Spring, S. (2020), "The limits of environmental accounting disclosure: enforcement of regulations, standards and interpretative strategies", Accounting, Auditing \& Accountability Journal, Vol. 33 No. 6, pp. 1367-1393.

Simnett, R., Vanstraelen, A. and Chua, W.F. (2009), "Assurance on sustainability reports: an international comparison", The Accounting Review, Vol. 84 No. 3, pp. 937-967.

Spence, C. (2007), "Social and environmental reporting and hegemonic discourse", Accounting, Auditing \& Accountability Journal, Vol. 20 No. 6, pp. 855-882.

Strang, D. and Soule, S.A. (1998), "Diffusion in organizations and social movements: from hybrid corn to poison pills", Annual Review of Sociology, Vol. 24, pp. 265-290.

Sudreau, P. (1976), "The reform of the enterprise", Accounting, Organizations and Society, Vol. 1 No. 1, pp. 97-99.

Sunstein, C.R. (1996), "Social norms and social roles", Columbia Law Review, Vol. 96, pp. 903-968.

Thomson, I. (2020), "From gray to green accounting", Social and Environmental Accountability Journal, Vol. 40 No. 3, pp. 205-08.

Toms, J.S. (2002), "Firm resources, quality signals and the determinants of crporation environmental reputation: some UK evidence", The British Accounting Review, Vol. 34 No. 3, pp. 257-282.

Tregidga, H., Milne, M. and Kearins, K. (2014), “(Re)presenting 'sustainable organizations”, Accounting, Organizations and Society, Vol. 39 No. 6, pp. 477-494. 
Unerman, J., Bebbington, J. and O'Dwyer, B. (2018), "Corporate reporting and accounting for externalities", Accounting and Business Research, Vol. 48 No. 5, pp. 497-522.

UNWCED (1987), Report of the World Commission on Environment and Development: Our Common Future, Oxford University Press, Oxford.

Zucker, L.G. (1977), "The role of institutionalization in cultural persistence", American Sociaological Review, Vol. 42 No. 5, pp. 726-743.

\section{Corresponding author}

Carlos Larrinaga can be contacted at: carlos.larrinaga@ubu.es
The prehistory of sustainability reporting

For instructions on how to order reprints of this article, please visit our website: www.emeraldgrouppublishing.com/licensing/reprints.htm Or contact us for further details: permissions@emeraldinsight.com 